\title{
ІНСТРУМЕНТИ ІНВЕСТИЦЙНО-ІННОВАЦЙНОГО ЗАБЕЗПЕЧЕННЯ РЕГІОНУ В УМОВАХ ДЕЦЕНТРАЛІЗАЦІЙНИХ ЗМІН
}

\author{
Луцький національний технічний університет
}

У статті розкрито передумови нарощення інвестиційно-інноваційного забезпечення регіону в умовах децентралізаційних змін. На основі аналізу кращих практик українських міст у нарощенні інвестиційно-інноваційного забезпечення розвитку регіону виокремлено умови нарощення регіонами ресурсної бази інвестицій в умовах децентралізації. Зокрема, до глобальних умов віднесено: актуальність законодавчих норм про інвестиційну діяльність та юридичну відповідальність за їх порушення; взаємну відповідальність задіяних в інвестиційному процесі суб'єктів; дотримання прав та свобод інвестора, розширення форм змішаного фінансування інвестпроектів тощо. Залучення достатнього розміру інвестицій для розвитку інноваційної сфери території передбачає ряд кроків: створення територіальних агенцій економічного розвитку; бенчмаркінг території; розробка інвестиційного паспорта, інвестиційного веб-порталу регіону, стандартних процедур роботи 3 інвесторами тощо; розробка інвестиційних порталів територій 3 інтерактивними онлайн-картами інвестоб'єктів та територіальної стратегії залучення інвестицій; облік та аналіз потенційних об'єктів для інвестування, людського потенціалу, логістики та суміжного бізнесу в регіоні; визначення пріоритетних сфер у регіоні для інвестування.

Наведено основні елементи системи інвестування на місцевому рівні. Зауважено, що дана система включає: інвестування фізичними/юридичними особами, заснованими на колективній власності; державне та місцеве інвестування; державна підтримка реалізації місцевих проєктів; іноземне та спільне інвестування

Дослідження інвестиційно-інноваційного забезпечення регіону в умовах децентралізаційних змін дозволило сформувати критерії інвестиційної привабливості об'єднаних громад. Зокрема, це: готовність території до інвестиційного процесу; відсутність проблем у питаннях прав власності на об'єкт інвестування; популяризувати інвестиційні переваги території, які властиві лише їй; прозорий правовий статус території; демонструвати позитивні економічні зміни регіону; узгодженість інвестицій, які залучаються в громаду.

Вагоме значення для активізації інвестпроцесів в Україні належить участі держави у фінансуванні проектів у т.ч інноваційних. Нині питома вага фінансування за кошти бюджетів різних рівнем $\epsilon$ незначною, що викликано браком ресурсної бази. Однозначно дана ситуація завдає негативних наслідків розвитку науково-інноваційної діяльності, тому автором подана систематизація інструментальної бази інвестиційно-інноваційного забезпечення територій в умовах децентралізації.

Ключові слова: адміністративно-територіальна реформа, інвестиційно-інноваційне забезпечення, децентралізація, об'єднані територіальні громади.

\section{INVESTMENT AND INNOVATION SUPPORT TOOLS REGION IN CONDITIONS OF DECENTRALIZATION CHANGE}

\author{
Lutsk National Technical University
}

The article reveals the preconditions for increasing the investment and innovation support of the region in the conditions of decentralization changes. Based on the analysis of the best practices of Ukrainian cities in increasing the investment and innovation support of the region's development, the languages of increasing the regions' resource base of investments in the conditions of decentralization are singled out. In particular, the global conditions include: the relevance of legislation on investment activities and legal liability for their violation; mutual responsibility of the subjects involved in the investment process; observance of the rights and freedoms of the investor, expansion of forms of mixed financing of investment projects, etc.

Attracting a sufficient amount of investment for the development of the innovation sphere of the territory involves a number of steps: the creation of territorial agencies of economic development; territory benchmarking; development of an investment passport, investment web portal of the region, standard procedures for working with investors, etc. Development of investment portals of territories with interactive online maps of investment objects and territorial strategy of investment attraction; accounting and analysis of potential objects for investment, human potential, logistics and related business in the region; identification of priority areas in the region for investment. 
The main elements of the investment system at the local level are presented. It is noted that this system includes: investment by individuals / legal entities based on collective ownership; state and local investment; state support for the implementation of local projects; foreign and joint investment.

The study of investment and innovation support of the region in the conditions of decentralization changes allowed to form the criteria of investment attractiveness of united communities. In particular, these are: readiness of the territory for the investment process; no problems with ownership of the object of investment; to popularize investment advantages of the territory, which are peculiar only to it; transparent legal status of the territory; demonstrate positive economic changes in the region; consistency of investments that are attracted to the community.

The participation of the state in financing projects, including innovative ones, is of great importance for the intensification of investment processes in Ukraine. Currently, the share of funding from budgets of different levels is insignificant, due to lack of resource base. Unequivocally, this situation has negative consequences for the development of scientific and innovative activities, so the author presents a systematization of the instrumental base of investment and innovation support of territories in the conditions of decentralization.

Key words: administrative-territorial reform, investment-innovation support, decentralization, united territorial communities.

Постановка проблеми у загальному вигляді i ïi зв'язок 3 важливими науковими та практичними завданнями. Адміністративно-територіальна реформа, назрівала ще з часів здобуття Україною незалежності і мала на меті через розвиток об’єднаних громад досягти зростання національної економіки. Процеси децентралізації, які беруть свій початок ще з 2014 року, сприяють сталому розвитку територій, у тому числі і завдяки залученню інвестицій. Дані рейтингу інвестиційної привабливості країн «Міжнародний бізнес-компас BDO» [1] за 2018 рік: Україна за рік піднялася на три позиції, підтверджують даний факт.

Модернізація моделей і форм інвестування, що, однозначно, позитивно позначається на розширенні джерел формування інвестиційного забезпечення регіону отримуємо як наслідок проведених реформ. «При об’єднанні громад будуть обрані нові лідери, зацікавлені у залучення сучасних інвестицій, що безумовно матиме позитивний вплив насамперед на наповнення місцевих бюджетів через оптимізацію сплати податків та створення належної інфраструктури ОТГ та ефективного розподілу бюджетних коштів і витрат» [2].

Позаяк суперництво за інвестиції сьогодні надзвичайно досить активне як на державному так і на місцевому рівнях, тому створення сприятливого інвестиційного клімату в регіонах і громадах є надзвичайно важливим завданням.

Аналіз останніх досліджень, у яких започатковано вирішення проблеми. Дослідженням інвестиційно-інноваційного забезпечення регіону в умовах децентралізаційних змін присвячено праці таких вітчизняних учених, як Бриль М., Івашина Л., Денисюк Г., Пальчук В., Сторонянської І., Гуренко А., Овчаренко Т., Москалюк Н. та ін. Віддаючи належне високому рівню наукових робіт, зазначимо, що недостатньо уваги все ж приділяється пошуку нових та посиленню діючих інструментів інвестиційно-інноваційного забезпечення територій в умовах поглиблення процесів децентралізації.

Цілі статті - дослідити та обгрунтувати інструменти інвестиційноінноваційного забезпечення територій в умовах поглиблення процесів децентралізації.

Виклад основного матеріалу дослідження 3 повним обгрунтуванням отриманих наукових результатів.

«Стабільний i динамічний економічний розвиток як великих, так й малих місцевих громад ускладнюється недостатністю інвестиційних ресурсів.

У цьому контексті поняття «інвестиції» трактують як вкладення ресурсів для одержання прибутку, проте на початку децентралізації інвестиційним проектам новостворених ОТГ притаманне саме соціальне спрямування. Такий напрям використання інвестиційних ресурсів пов'язаний 3 основною метою реформи децентралізації - підвищення якості життя, ефективності та доступності послуг для членів громади [3]. 
Нарощення інноваційно-інвестиційного забезпечення регіону в умовах децентралізаційних змін передбачає при виборі форм i методів інвестування враховувати специфіку діяльності регіону, динамічно реагувати на виклики часу, вдосконалювати механізми захищеності інвестицій.

Форми інвестиційно-інноваційного забезпечення розвитку регіону за своєю квінтесенцією визначають джерело інвестування (1).

Форма
інвестування
Бюджетне інвестування
Інвестування за рахунок
власних коштів підприємств,
організацій
Інвестування за рахунок
кредитів і позик
Внутрішні та зовнішні
інвестиції
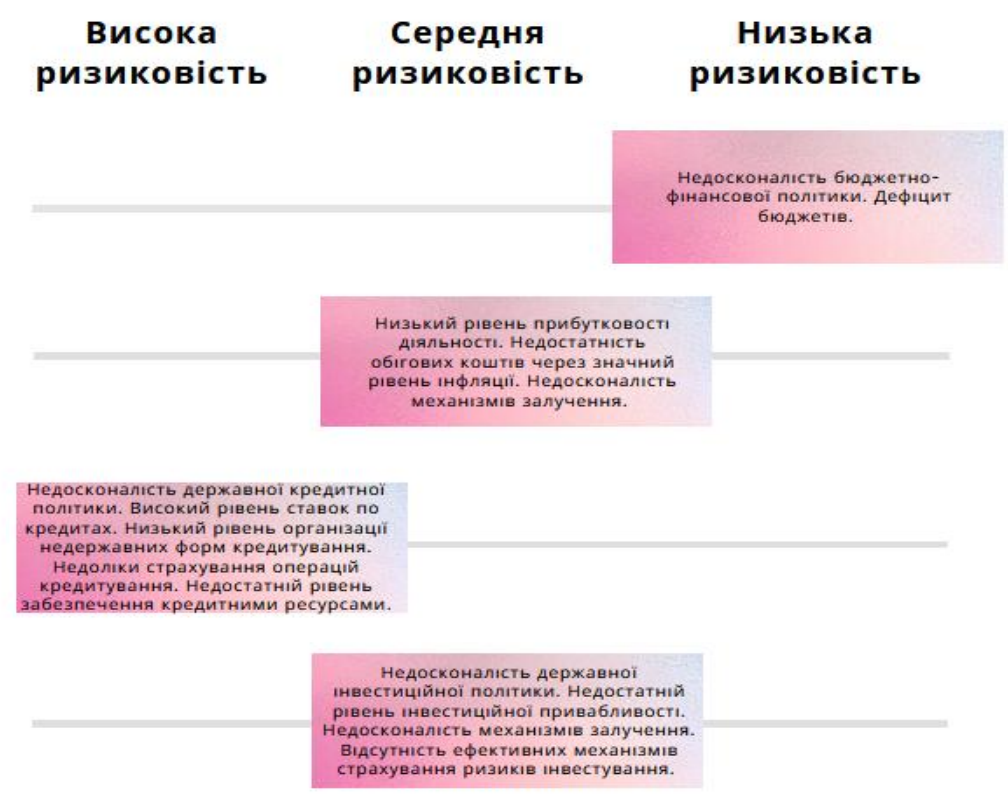

Рис.1. Форми інвестиційно-інноваційного забезпечення розвитку регіону

Будь, яка 3 представлених форм інвестування несе в собі ризиковість. Так, для бюджетного інвестування характерна низька ризиковість. Джерелами інвестування при цьому виступають кошти бюджетів різних рівнів та позабюджетних фондів залучені на безповоротній основі; фінансові ресурси утворені в процесі перерозподілу бюджетних коштів, дотацій та пільг в оподаткуванні. Середня ризиковість притаманна внутрішнім та зовнішнім інвестиціям та інвестуванню за рахунок власних коштів підприємств та організацій. Щодо останніх то такі інвестиції здійснюються за рахунок «нерозподіленого прибутку, який залишається у розпорядженні підприємства, організації; дивідендів, що направляються на інвестування; частини позаоборотних активів, які реінвестують; частини оборотних активів, яка іммобілізується в інвестиції; коштів від розміщення депозитів; коштів, які виплачуються державними органами та органами страхування у вигляді відшкодування збитків; коштів від емісії цінних паперів; вкладень інвестора в статутний фонд підприємства; коштів від розміщення цінних паперів на вторинному ринку; кошти недержавних організацій, які надаються на цільове інвестування на безповоротних засадах; факторингу» [4].

Кращі практики українських міст у нарощенні інвестиційно-інноваційного забезпечення розвитку регіону подані у табл. 1.

Зазначимо, що інвестиційно-інноваційного забезпечення розвитку регіону не можливе без розробки інвестиційного паспорту території, інвестиційного веб-порталу; створення індустріального парку; інформації про кадрове забезпечення регіону; інформації про якість транспортного сполучення та доступ до центральних магістралей; підготовки методичних рекомендацій по роботі 3 потенційними інвесторами та інструментів зворотного зв'язку, проведення на постійній основі тренінгів, круглих столів та інших видів активностей 3 внутрішніми та зовнішніми стейкхолдерами, проведення опитувань тощо. 
Кращі практики українських міст у нарощенні

інвестиційно-інноваційного забезпечення розвитку регіону

\begin{tabular}{|c|c|c|}
\hline Регіон & Досягнення & Напрацьовані інструменти \\
\hline $\begin{array}{l}\text { Вінницька } \\
\text { область }\end{array}$ & $\begin{array}{l}\text { Вперше створенно Агенцію регіонального розвитку. } \\
\text { Розроблено: Програму сприяння залученню інвестицій у Вінницьку міську об’єднану } \\
\text { територіальну громаду; Інвестиційний паспорт міста Вінниця; Інвестиційний портал Invest in } \\
\text { Vinnytsia; Гід інвестора; Маркетингову стратегію Вінниці; бренд міста. } \\
\text { Створено низку індустріальних парків та муніципального інноваційно-технологічного парку, } \\
\text { на базі якого формується екосистема підтримки підприємництва, стартапів, наукових } \\
\text { розробок. }\end{array}$ & $\begin{array}{l}\text { Навчання з місцевого економічного розвитку для представників об’єднаних територіальних громад } \\
\text { Організація та проведення Міжнародного інвестиційного форуму «Вінниччина - бізнес у центрі } \\
\text { України». } \\
\text { Наявність стандартів роботи та супроводу інвесторів, які включають систему «єдиного вікна»та } \\
\text { алгоритм внутрішньої взаємодії виконавчих органів міської ради } 3 \text { розгляду й опрацювання } \\
\text { інвестиційних пропозицій }\end{array}$ \\
\hline $\begin{array}{l}\text { Полтавська } \\
\text { область }\end{array}$ & $\begin{array}{l}\text { За останні п’ять років область постійно входить до першої десятки областей країни у сфері } \\
\text { залучення інвестицій. Полтавщина зосередила на своїх теренах } 244 \text { інвестиційних } \\
\text { підприємств, які акумулюють вкладення із } 43 \text { країн світу. Основними країнами-інвесторами } \epsilon \\
\text { Велика Британія, Швейцарія та Нідерланди. } \\
\text { Інвестиційний паспорт Полтавської області. } \\
\text { Інвестиційний портал Полтавщини. } \\
\text { Ведеться активна робота по створенню індустріальних парків в області }\end{array}$ & $\begin{array}{l}\text { Проведення міжнародних інвестиційних та економічних форумів: у } 2017 \text { році - «Полтавщина: } \\
\text { створюємо разом нові можливості», а у 2018-му - «Діалогова платформа \#Полтавщина } \\
\text { інвестиційна» } \\
\text { Розробка навчальної програми із застосування інвестиційних інструментів, за підсумками якої } \\
\text { громади не лише навчилися ефективно аналізувати свій економічний потенціал та інвестиційну } \\
\text { привабливість, а й формувати свої інвестиційні паспорти. За результатами навчання проводитьяя } \\
\text { конкурс паспортів громад. }\end{array}$ \\
\hline $\begin{array}{l}\text { м. Кременчук } \\
\text { Полтавської } \\
\text { області }\end{array}$ & $\begin{array}{l}\text { Міська програма сприяння залученню інвестицій та розвитку міжнародного співробітництва } \\
\text { Кременчука на 2019-2021 роки } \\
\text { комунальне підприєсств «Кременчуцький центр міжнародних зв’язків і економічного } \\
\text { розвитку міста «Інститут розвитку Кременчука» } 24 \text { (скорочено: КП «Інститут розвитку } \\
\text { Кременчука»), яке функціонує, зокрема, для підтримки інвестиційної діяльності в місті. } \\
\text { Інвестиційний паспорт міста Кременчук, який оприлюднено на веб-сайті КП «Інститут } \\
\text { розвитку Кременчука». }\end{array}$ & $\begin{array}{l}\text { Проведення на постійній основі тренінгу із підготовки інвестиційних проектів для представників } \\
\text { структурних підрозділів виконавчого комітету Кременчуцької міської ради, представників } \\
\text { комунальних підприємств міста і громадських організацій } \\
\text { Проведення бізнес-форумів «Міжнародне співробітництво: створюємо майбутнє разом». }\end{array}$ \\
\hline $\begin{array}{c}\text { Запорізька } \\
\text { область }\end{array}$ & $\begin{array}{l}\text { Розробка Інвестиційного паспорта (більшість ОТГ Запорізької області мають власні } \\
\text { стандартизовані інвестиційні паспорти) та Інвестиційного порталу Запорізької області. } \\
\text { Розроблення Методології та стандартів залучення та супроводу інвесторів у Запорізькій } \\
\text { області. } \\
\text { Створення екотехнопарку ТЕСНІА. }\end{array}$ & $\begin{array}{l}\text { Розроблені технічні прийоми спілкування з інвесторами. } \\
\text { Проект ПРОМІС у співпраці з управлінням зовнішніх зносин та зовнішньоекономічної діяльності } \\
\text { Запорізької ОДА провів низку навчальних заходів, під час яких громади навчалися повноцінно } \\
\text { використовувати свої можливості щодо залучення інвесторів. } \\
\text { Інвестиційний форум InCо Forum. Відзнято якісне промоційне відео регіону }\end{array}$ \\
\hline $\begin{array}{l}\text { м. Мелітополь } \\
\text { Запорізької } \\
\text { області }\end{array}$ & $\begin{array}{l}\text { 19-та сходинка 3-поміж } 100 \text { найбільших міст України в рейтингу прозорості інвестиційного } \\
\text { сектору Transparency International Україна. } \\
\text { Посідас 6-те місце в міжнародному рейтингу журналу FDI Intelligence, що є частиною } \\
\text { Financial Times, у підкатегорії «Економічна ефективність» категорії «Стратегія прямих } \\
\text { іноземних інвестицій». Діє Комплексна міська програма «Сприяння розвитку } \\
\text { підприємництва в місті Мелітополі Запорізької області. } \\
\text { Функціонує Агенція розвитку Мелітополя. } \\
\text { Розроблено: Інвестиційний портал Мелітополя; Інвестиційний паспорт міста. }\end{array}$ & $\begin{array}{l}\text { Актуальність інформації на інфоресурсах для локальних малих і середніх підприємств про можливі } \\
\text { напрями інноваційно-інвестиційної співпраці. }\end{array}$ \\
\hline $\begin{array}{l}\text { Івано- } \\
\text { Франківська } \\
\text { область }\end{array}$ & $\begin{array}{l}\text { За обсягом іноземних інвестицій на одного жителя область увійшла до національної п’ятірки } \\
\text { найкращих. Інвестиції надходять від нерезидентів із майже } 50 \text { країн світу. } \\
\text { Діє Регіональна цільова програма сприяння залученню інвестицій в економіку області. } \\
\text { Розроблено Інвестиційний паспорт області }\end{array}$ & $\begin{array}{l}\text { Розроблено дорожню карту координації діяльності учасників інвестиційних процесів } \\
\text { Вільний доступ до статистичної інформації області, про її потужності та потенційно привабливі } \\
\text { зони для інвесторів. }\end{array}$ \\
\hline $\begin{array}{l}\text { Івано- } \\
\text { Франківськ } \\
\text { Івано- } \\
\text { Франківської } \\
\text { області }\end{array}$ & $\begin{array}{l}\text { Розроблення Інвестиційного порталу Івано-Франківська та інвестиційної інтерактивної } \\
\text { карти, на якій відображено індустріальні парки - підготовлені земельні ділянки та будівлі } \\
\text { (Greenfield та Brownfield об’єкти) міста. } \\
\text { Інвестиційний паспорт у двох мовних варіантах - українською та англійською - розміщено } \\
\text { на офіційному сайті Івано-Франківська }\end{array}$ & $\begin{array}{l}\text { У вільному доступі вся наявна інформація про вільні земельні ділянки та виробничі площі для } \\
\text { реалізації інвестиційних проектів, а також презентовано успішно реалізовані інвестиційні проекти. } \\
\text { На додаток на порталі розміщено інвестиційну інтерактивну карту, на якій відображено } \\
\text { індустріальні парки - підготовлені земельні ділянки та будівлі (Greenfield та Brownfield об’єкти) } \\
\text { міста. } \\
\text { Проведення на постійній основі Міжнародного інвестиційно-економічномго форуму «Партнерство } \\
\text { і перспектива». }\end{array}$ \\
\hline
\end{tabular}


Перешкодами залучення зовнішніх фінансових (інвестиційних) ресурсів для громади/регіону наведено на рисунку 2.

Зауважимо, що до основних перешкод нарощення регіонами ресурсної бази інвестицій можна віднести такі: корупція, адміністративні перепони для функціонування бізнесу, «недостатність інформації щодо потенційних інвестиційних об'єктів, які наявні в громаді (кадастр промислових земель, реєстр існуючих об'єктів нерухомості тощо); проблеми, які зумовлені недоліками у законодавстві (зокрема, часті зміни в нормативно-правових актах стосовно діяльності територій); тривалі бюрократичні процедури, які стосуються започаткування та функціонування суб'єктів підприємництва; брак кваліфікованих спеціалістів, які відповідають за економічний розвиток громади та залучення інвестицій; не налагодженість комунікації з бізнес спільнотою громади/регіону; недостатність/недоступність грантових програм [5,c. 42; 6, c. 317].

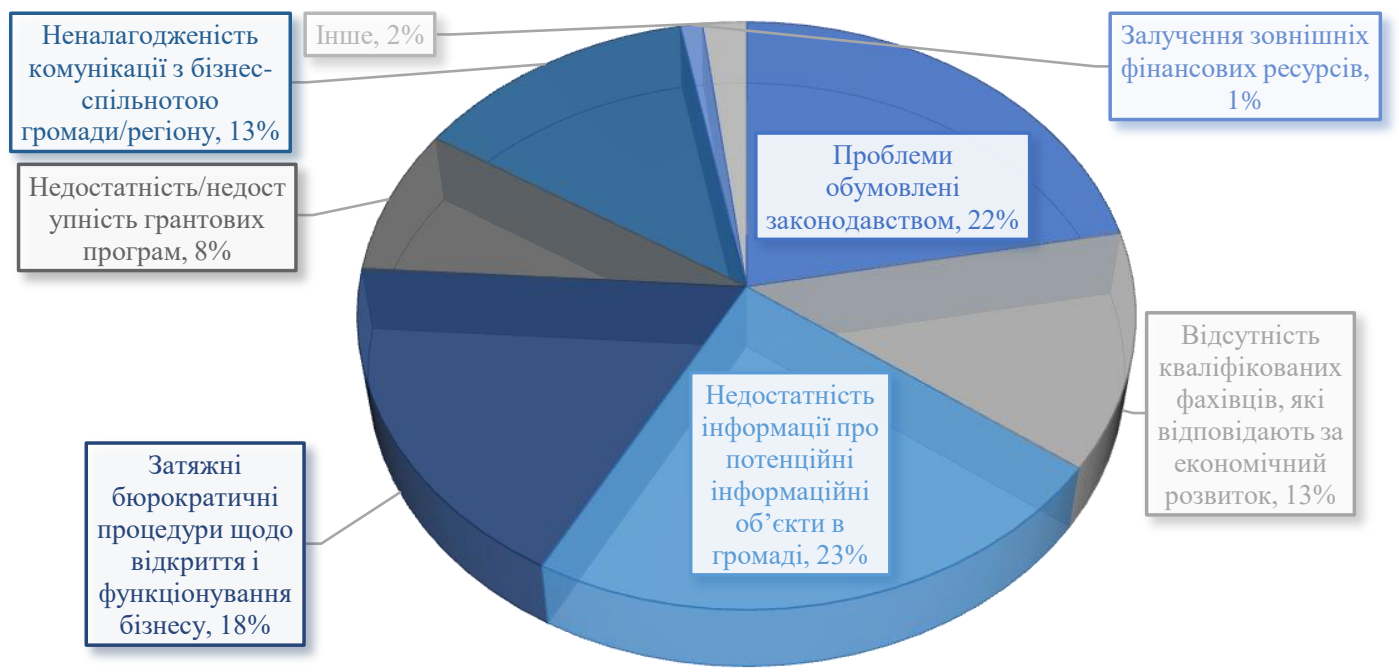

Рис. 2. Перешкоди залучення зовнішніх фінансових (інвестиційних) ресурсів для громади/регіону [6]

Для того щоб формувати оптимальний обсяг інвестиційних ресурсів та забезпечити ефективність залучення нових джерел інвестування необхідно дотримуватися певних умов (рис. 3 ).

До глобальних умов відносимо: актуальність законодавчих норм про інвестиційну діяльність та юридичну відповідальність за їх порушення; взаємну відповідальність задіяних в інвестиційному процесі суб'єктів; дотримання прав та свобод інвестора, розширення форм змішаного фінансування інвестпроектів тощо.

Умовах децентралізації, регіону в інвестиційно-інноваційному забезпеченні належить ключова роль. Залучення достатнього розміру інвестицій для розвитку інноваційної сфери території передбачає ряд кроків: створення територіальних агенцій економічного розвитку; бенчмаркінг території; розробка інвестиційного паспорта, інвестиційного веб-порталу регіону, стандартних процедур роботи з інвесторами тощо; розробка інвестиційних порталів територій з інтерактивними онлайн-картами інвест об'єктів та територіальної стратегії залучення інвестицій; облік та аналіз потенційних об'єктів для інвестування, людського потенціалу, логістики та суміжного бізнесу в регіоні; визначення пріоритетних сфер у регіоні для інвестування.

Варто зазначити, що інвестиційні проекти територій варто продукувати адекватно до сформованих оперативних цілей стратегії розвитку регіону із 
конкретизацією їх наближеної вартості та джерел фінансування та обов'язковим розміщенням на веб-сайті громади.

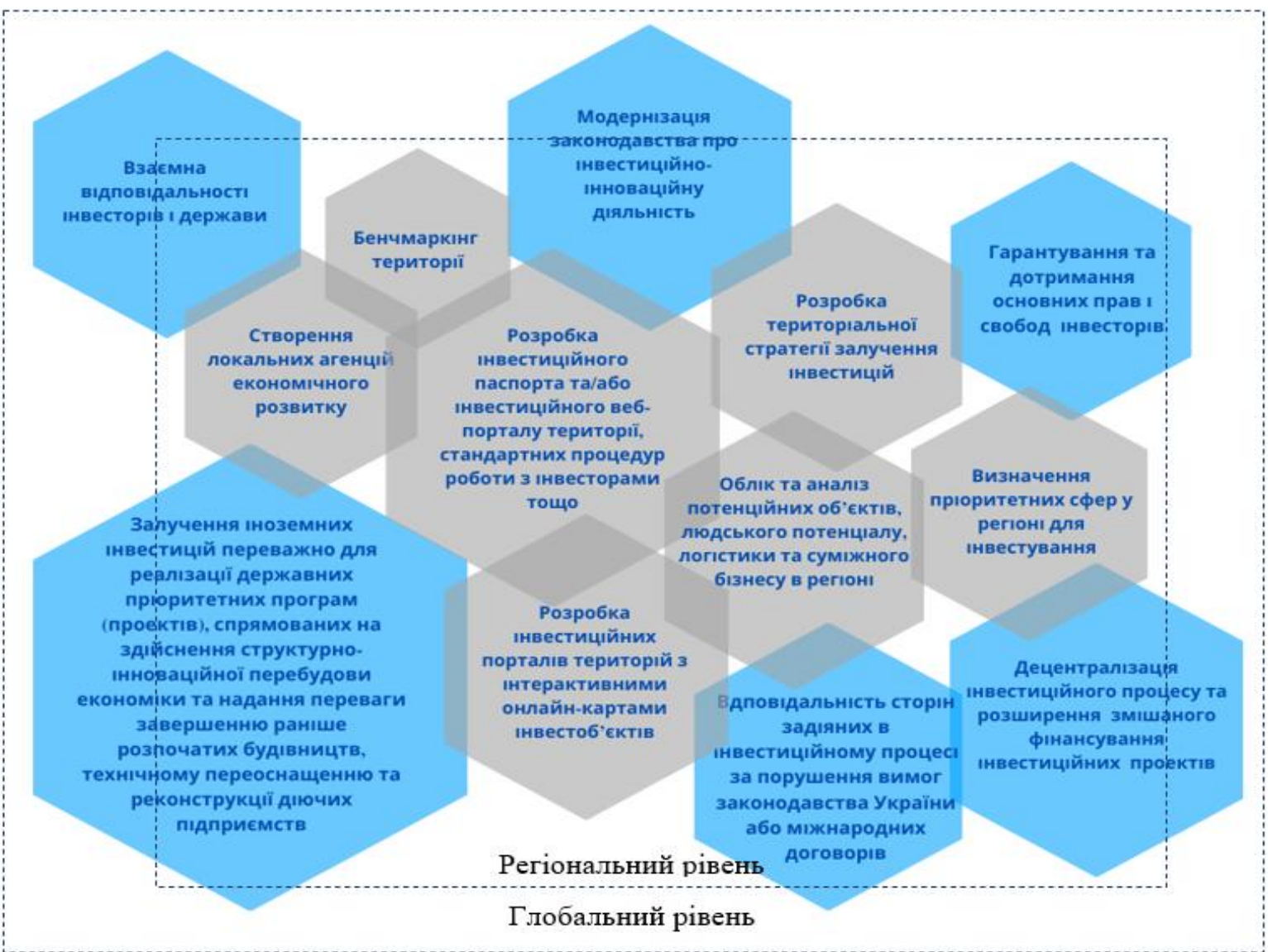

Рис. 3. Умови нарощення регіонами ресурсної бази інвестицій в умовах децентралізації

Нині багатообіцяючими для ОТГ з позицій інвестування є проєкти пов'язані 3 енергоефективністю та альтернативною енергетикою; підтримкою місцевого бізнесу; екологією, розвитком цифрових технологій; покращенням транспортного з'єднання; випуском нових видів продукції та розвитком туризму і спорту.

Відбір інвестпроєктів, які, для прикладу, реалізовуватимуться на території об'єднаних громад передбачають залучення органами місцевого самоврядування іiі мешканців до даного процесу, через активну інформатизацію та відкритість, прозорість критеріїв відбору проектів. Залучення громадскості може відбуватися через організацію круглих столів 3 проблемних питань; опитування та дослідження громадської думки; формування фокус груп для вирішення проблемних питань та громадські обговорення.

Інвестування на місцевому рівні та сприяння реалізації інвестиційних проєктів в межах коштів місцевого бюджету та/або позик, отриманих під місцеві гарантії, провадяться в порядку, встановленому органами місцевого самоврядування, відповідно до вимог чинного законодавства. Загальна система інвестування на місцевому рівні подана на рис. 4.

Загальна система інвестування на місцевому рівні включає: інвестування фізичними/юридичними особами, заснованими на колективній власності; державне та місцеве інвестування; державна підтримка реалізації місцевих проєктів; іноземне та спільне інвестування. Інвестування фізичними/юридичними особами, заснованими на колективній власності відбувається громадянами, підприємствами не державної форми власності, господарськими асоціаціями, спілками i товариствами, а також 
громадськими та релігійними організаціями, іншими юридичними особами, заснованими на колективній власності.

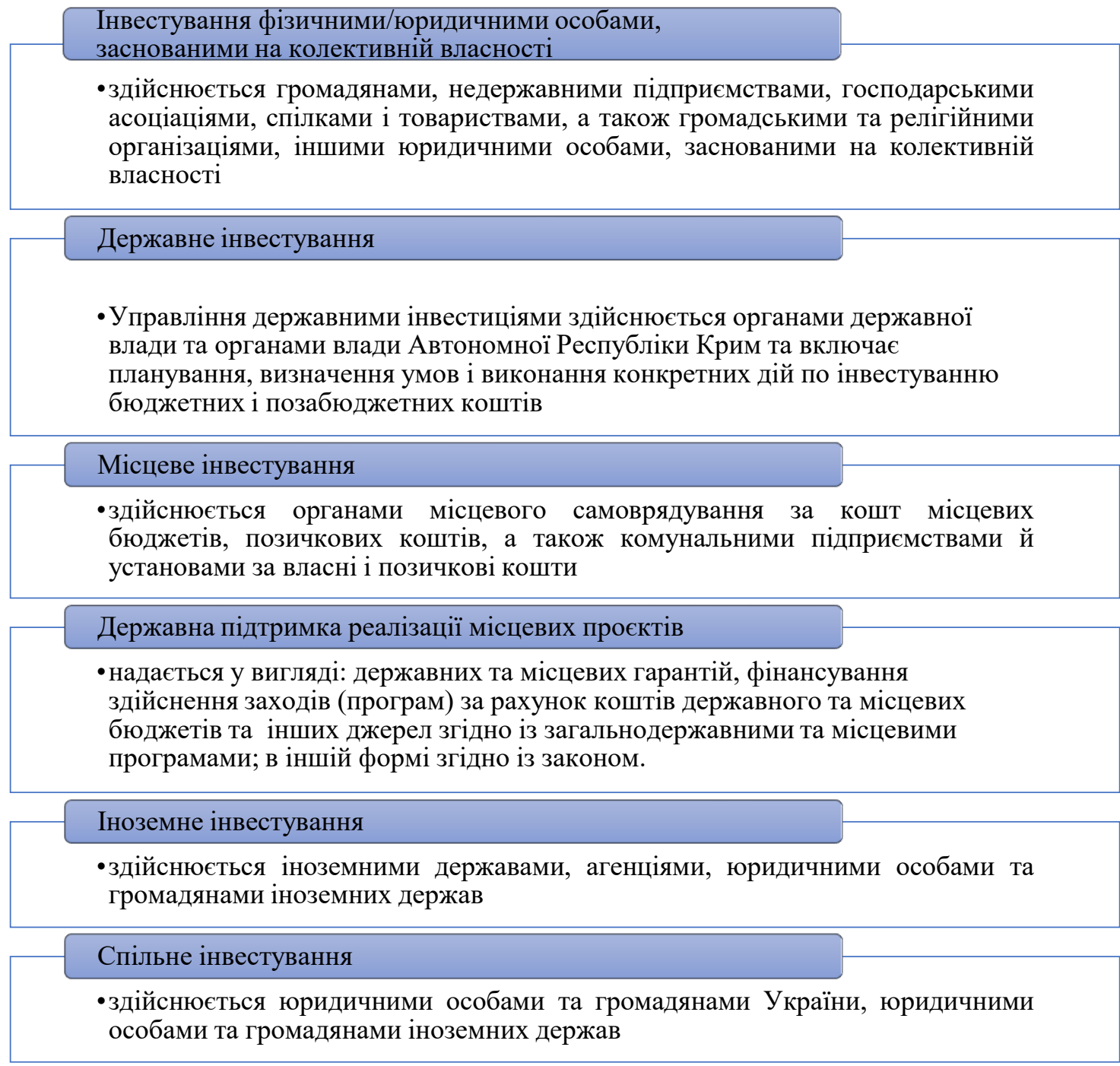

Рис. 4. Система інвестування на місцевому рівні

Сформовано автором на основі [8], [9]

Державне інвестування передбачає планування, визначення умов і виконання конкретних дій по інвестуванню бюджетних і позабюджетних коштів. Місцеве інвестування ініціюється органами місцевого самоврядування за кошти місцевих бюджетів, позичкових коштів, а також комунальними підприємствами й установами за власні і залучені кошти.

Державна підтримка реалізації місцевих проєктів надається у вигляді: державних та місцевих гарантій, фінансування заходів (програм) за рахунок коштів бюджетів різних рівнів та інших джерел згідно із загальнодержавними та місцевими програмами; в іншій формі відповідно до чинного законодавства.

Іноземне інвестування здійснюється іноземними державами, агенціями та іншими не резидентами. Спільне інвестування ведеться юридичними особами та громадянами України, юридичними особами та громадянами іноземних держав.

Інструменти інвестиційно-інноваційного забезпечення територій в умовах децентралізації систематизовано у табл. 2.

Вагоме значення для активізації інвестпроцесів в Україні належить участі держави у фінансуванні проектів у т.ч інноваційних. Нині питома вага фінансування за кошти бюджетів різних рівнем $є$ незначною, що викликано браком ресурсної бази. 
Інструменти інвестиційно-інноваційного забезпечення територій в умовах децентралізації

Інструменти інноваційноінвестиційного забезпечення

\begin{tabular}{|c|c|}
\hline Місцеві запозичення & $\begin{array}{c}\text { Міські ради, зокрема ради міських } \\
\text { ОТГ, мають право здійснювати } \\
\text { місцеві запозичення (ст. } 16 \\
\text { Бюджетного кодексу України) до } \\
\text { своїх бюджетів - як внутрішні, так } \\
\text { і зовнішні, в тому числі шляхом } \\
\text { отримання кредитів (позик) від } \\
\text { міжнародних фінансових } \\
\text { організацій. }\end{array}$ \\
\hline $\begin{array}{c}\text { Корпоратизація комунальних } \\
\text { підприємств }\end{array}$ & $\begin{array}{c}\text { громада може зберегти права } \\
\text { власності на комунальне } \\
\text { підприємство, але водночас } \\
\text { позбутися відповідальності за } \\
\text { його зобов'язання; залучити до } \\
\text { підприємства інвестиційні кошти, } \\
\text { але зберегти за собою контрольні } \\
\text { чи блокувальні повноваження або } \\
\text { повністю приватизувати } \\
\text { комунальне підприємство. }\end{array}$ \\
\hline Гранти & $\begin{array}{c}\text { грошові або інші засоби, що } \\
\text { передаються громадянами та } \\
\text { юридичними особами (у тому } \\
\text { числі іноземними), а також } \\
\text { міжнародними організаціями для } \\
\text { проведення конкретних наукових } \\
\text { досліджень, розробки } \\
\text { законопроєктів, підготовки кадрів } \\
\text { та інших цілей на умовах, } \\
\text { передбачених грантодавцем }\end{array}$ \\
\hline $\begin{array}{l}\text { Міжмуніципальне } \\
\text { співробітництво }\end{array}$ & $\begin{array}{c}\text { органи місцевого самоврядування } \\
\text { на договірній основі об'єднують }\end{array}$ \\
\hline
\end{tabular}

\section{Спрямування}

спрямовуються на реалізацію

інвестиційних програм (проєктів),

метою яких є розвиток комунальної інфраструктури, впровадження ресурсозберігаючих технологій, створення, приріст чи оновлення стратегічних об'єктів

довготривалого користування або об'єктів, які забезпечують

виконання завдань міських рад, спрямованих на задоволення інтересів населення їх громад

залучення додаткових надходжень шляхом передачі корпоративних прав на унітарне комунальне підприємство (або частини таких прав) приватним інвесторам та його перетворення на корпоративне

За допомогою грантів

Можливим $є$ залучення окремих секторів, значущих для

Супутні ризики

Таблиця 2

Форми

надмірне зростання боргового навантаження, яке місцеві

бюджети не зможуть

обслуговувати (або

обслуговуватимуть за рахунок

зменшення важливих соціальних витрат)

Процеси корпоратизації залежат від політичної ситуації, а також інтересів впливових фінансовопромислових груп «укладення договорів позики (кредитних договорів);

емісії облігацій місцевих позик» [10]

\section{Досвід України:} приватизація, корпоратизація об'єднань підприємств, і створення холдингових компаній.

Закордонний досвід:

«часткова приватизація та змішана форма власності підприємств; їх повна приватизація із залученням стратегічного зарубіжного партнера; збереження підприємств у державній / комунальній власності» [11]

«регіональні або місцев грантові програми;

Автори грантової заявки подеколи характеризуються недостатнім досвідом і низькою фаховістю виконавців проєкту

гранти при посольствах; спеціальні програми «малих грантів»;

спільні програми в рамках

$$
\text { Євросоюзу» [12] }
$$

співфінансування,

Загроза місцевій автономії реалізація спільного 
свої ресурси та зусилля для розвитку. $€$ характерним для децентралізованої територіальної адміністративної системи

механізм виконання інвестиційних програм і проєктів регіонального розвитку (у тому числі проєктів співробітництва та добровільного

об'єднання територіальних

громад), що мають на меті розвиток регіонів, створення Державного фонду регіонального розвитку (ДФРР) рораструктури, індустріальних та інноваційних парків і визначеним у Державній стратегії

регіонального розвитку та відповідних стратегіях розвитку регіонів.

Мінфін здійснює розміщення короткострокових облігацій внутрішніх державних позик

Отримання додаткових надходжень у вигляді процентних доходів

України під річ

$є$ значно вищим, ніж відсоток, що вирішення загальних проблем відповідають пріоритетам, насамперед має бути спрямований пропонують банківські установи

за короткостроковими депозитами.. функціональної території, наприклад сільськогосподарська або промислова орієнтованість

Проєкт регіонального розвитку

на розвиток інфраструктури,

підприємництва, давати

мультиплікаційний ефект.

Менший ступінь залучення кожного громадянина і врахування його думки

Менша взаємодія з приватним сектором.

Обмежена гнучкість

Проектам економічного спрямування громади приділяють менше значення, ніж для прикладу проектам з ремонту доріг.

Відсутність стратегічного бачення органів місцевого самоврядування розвитку громади в середньо- та довгостроковій перспективі.

Недофінансування проектів.

«Відсутність критеріїв відбору членів регіональних конкурсних комісій та їх відповідальності за прийняті рішення; наявність можливості «проштовхування» народними депутатами, включеними до складу комісії $з$ відбору проектів, інтересів

окремих громад (подекуди шляхом тиску на членів комісії); слабо організований процес прозорост висвітлення відбору, реалізації та стану виконання проектів» [13]. розмішенням коштів місцевих бюджетів у державні облігації досить новий вид операцій і на початку вимагатиме більшої уваги для проведення всіх необхідних

місцевих бюджетів та отрил додатковий фінансовий ресурс у вигляді відсоткового доходу для фінансування пріоритетних видатків регіонів.

$$
\text { процедур. }
$$

Відсутність попиту на облігації, ризик недоотримання очікуваного прибутку проекту, створення

спільного органу

управління, створення

комунального підприємства

та делегування

повноважень

Всеукраїнський громадський бюджет (ВГБ) та ін .

облігації внутрішньої державної позики (далі ОВДП або державні

$$
\text { облігації) }
$$

розміщення тимчасово

вільних коштів місцевих

бюджетів на депозитах 
Однозначно дана ситуація завдає негативних наслідків розвитку науковоінноваційної діяльності. Зауважимо, що кожного року «на фінансування проектів через ДФРР у державному бюджеті повинні виділяти кошти у сумі не менше $1 \%$ прогнозного обсягу доходів загального фонду держбюджету на відповідний рік. Проте дана норма 3 2016 року призупинена і сума виділених коштів до 1\% не дотягує. Наприклад, на 2019 рік виділено 7,7 млрд. грн, або неповних 0,8\% усіх доходів загального фонду держбюджету.

Тобто, один з найпрогресивніший механізмів державної фінансової підтримки розвитку регіонів недофінансовують. Загалом, починаючи з 2015 року, на проекти регіонального розвитку з держбюджету виділили 23,1 млрд. грн» [13].

Ще однією проблемою в даній площині є те, що громади нівелюють проекти економічного спрямування, а надають першочергово перевагу поточним інфраструктурним питанням. Тому можемо з впевненістю говорити про відсутність стратегій розвитку в середньо- та довгостроковій перспективі.

Якщо говорити про фінансування проєктів коштом Державного фонду регіонального розвитку то тут теж наштовхуємося на бюрократично-процедурні перешкоди: нечіткість критеріїв відбору членів регіональних конкурсних комісій; лобіювання окремих проектів; недостатня прозорість відбору проектів та ін.

Місцеві запозичення можна віднести до ризикових інструментів інвестиційноінноваційного забезпечення територій, оскільки можуть сприяти надмірному борговому навантаженню, яке місцеві бюджети не зможуть обслуговувати, або обслуговуватимуть за рахунок скорочення важливих соціальних витрат. Хоча не можна не враховувати їх важливість в реалізації інвестиційних програм територій через задоволення інтересів населення їх громад. Вони спрямовуються на комунальної інфраструктури, впровадження ресурсозберігаючих технологій, створення, приріст чи оновлення стратегічних об'єктів довготривалого користування та ін.

Залучення об’єднаними громадами додаткових надходжень шляхом передачі корпоративних прав або їх частини на унітарне комунальне підприємство приватним інвесторам та його перетворення на корпоративне дозволяє зберегти права власності на комунальне підприємство, але водночас позбутися відповідальності за його зобов'язання; залучити до підприємства інвестиційні кошти, зберігаючи за собою повноваження власника. Ризики у цій площині пов'язані політичною ситуацією в країні, а також інтересів впливових фінансово-промислових груп.

Незалежно від того, наскільки громада спроможна, завжди залишаються питання, які важко вирішити за рахунок місцевого бюджету, однак можна це реалізувати за допомогою грантових програм. За допомогою яких здійснюється підтримка не прибуткових проєктів, котрі відіграють важливу роль у розвитку громади.

Відмітимо, що «міжмуніципальне співробітництво та налагодження партнерства органів місцевого самоврядування для реалізації спільних проектів - загальноприйнята модель об'єднання зусиль у країнах Європейського Союзу. Кожний третій проект громад у Німеччині - це проекти міжмуніципального співробітництва (MMC), у Франції в проектах ММС беруть участь 80\% громад. В Україні ж на цей момент діє 187 проектів ММС» [14]. Для органів місцевого самоврядування даний інструмент цікавий 3 точки зору вирішення нагальних проблем розвитку територій об'єднуючи на договорній основі свої ресурси та зусилля. Зауважимо, що МMC може використовуватися лише для децентралізованої територіальної адміністративної системи і реалізовуватися у формах співфінансування, реалізації спільного проекту, створення спільного органу управління, створення комунального підприємства. Хоча ММС вирівнює розподіл ресурсів в різних громадах, сприяє вирішенню більш складних завдань, однак негативним моментом при цьому може стати загроза місцевій автономії обмежена та гнучкість проектів.

Отримання додаткових надходжень у вигляді процентних доходів громадами можливе двома шляхами - за допомогою облігацій внутрішньої державної позики 
(ОВДП) та через розміщення тимчасово вільних коштів місцевих бюджетів на депозитах.

Ефективність використання тимчасово вільні кошти місцевих бюджетів громадами забезпечується через проведення операцій з державними цінними паперами, зокрема ОВДП.

Інвестиції в ОВДП відносно новий інструмент і в цілому вимагає більшої уваги від ОМС при проведенні всіх необхідних процедур. Ключовою перевагою ОВДП $є$ їх надійність і прибутковість, оскільки виплати мають 100\% гарантію держави.

Надходження до місцевих бюджетів у вигляді сплачених банками відсотків за їх користування склали «у 2018 році 1,3 млрд грн, що становить 0,6\% від суми доходів загального фонду місцевих бюджетів України (без урахування трансфертів 3 державного бюджету» [9].

ОВДП можуть бути продані в будь-який момент у разі потреби, в той час як депозит часто не може бути розірваний.

Варто врахувати ОМС, що облігації внутрішньої державної позики «мають більшу доходність, ніж банківські депозити: доходність облігацій внутрішньої державної позики зі строком розміщення на 3 місяці становить $19 \%$ річних, на 6, 9 та 12 місяців - 18 \% річних. При цьому поточна середньозважена вартість строкових депозитів у національній валюті складає близько 15,4 \% (за інформацією Національного банку України)» [15].

Розглянуті інструменти інвестиційно-інноваційного забезпечення набувають своєї актуальності виключно за умови добре підготовленої «інвестиційної території» 3 ефективним управлінням.

Для об'єднаних громад щоб бути привабливими для інвестора потрібно забезпечити: готовність території до інвестиційного процесу; відсутність проблем у питаннях прав власності на об'єкт інвестування; популяризувати інвестиційні переваги території, які властиві лише їй; прозорий правовий статус території; демонструвати позитивні економічні зміни регіону; узгодженість інвестицій, які залучаються в громаду.

До найпопулярніших форм створення інвестиційних територій нале-жать: «спеціальні економічні зони (великі території, звільнення від податків, управління органами торгівельного права); зони економічної діяльності (площа від кількох до кількох десятків гектарів, приналежність до одного органу місцевого самоврядування, відсутність відокремлених форм управління); технополіси, промислові парки, технологічні парки (від кількох до кількох десятків гектарів, акціонерні товариства, вибірковий прийом інвесторів - секторний підхід, території для стартапів інкубатори)» [16].

Органам місцевого самоврядування для забезпечення інвестиційно-іноваційного розвитку регіону потрібно вибрати інститут управління інвестиційною територією (рис.5).

\begin{tabular}{|c|c|}
\hline озвитку & $\begin{array}{l}\text { агенції регіонального чи місцевого розвитку: акціонерні товариства, товариства з обмеженою } \\
\text { відповідальністю, відкриті товариства, неурядові організації (фонди, об'єднання), які мають дозвіл } \\
\text { на ведення економічної діяльності; ці організації можуть мати різну ступінь участі державного } \\
\text { партнера - від володіння } 51 \% \text { акцій до } 100 \% \text { власності }\end{array}$ \\
\hline $\begin{array}{l}\text { комунальні установи, } \\
\text { створені спеціально для } \\
\text { управління територіями }\end{array}$ & $\begin{array}{l}\text { не мають самостійних повноважень у сфері, наприклад, продажу територій, інвестування на цих } \\
\text { територіях, але виконують управлінські, адміністративні та організаційні функції на вибраній } \\
\text { території; установи створюються і ліквідуються місцевими органами влади (радами), фінансуються } 3 \\
\text { бюджету. }\end{array}$ \\
\hline $\begin{array}{l}\text { органи в рамках } \\
\text { структури державної } \\
\text { установи }\end{array}$ & $\begin{array}{l}\text { відділ розвитку чи відділ підтримки підприємництва, які здійснюють делеговані їм функції в } \\
\text { межах структури державної установи }\end{array}$ \\
\hline $\begin{array}{c}\text { установи з бізнес- } \\
\text { оточення }\end{array}$ & $\begin{array}{l}\text { торгово-промислові палати, галузеві корпорації (наприклад, будівельна палата, спілка інженерів), } \\
\text { клуби підприємництва, інкубатори підприємництва, місцеві ініціативи (агенції), які діють на } \\
\text { повіреній держаним партнером території на підставі угоди (або передачі права власності) }\end{array}$ \\
\hline
\end{tabular}


Рис. 5. Інститути управління інвестиційною територією

Сформовано автором на основі [16]

Дієвими інститутами управління інвестиційною територією громади $\epsilon$ корпорація розвитку, спеціально створені комунальні установи, органи в рамках структури державної установи, бізнесові установи.

Висновки. Проведене у статті дослідження дає можливість говорити про важливість нарощення інвестиційно-інноваційного забезпечення для територій, що зазнали децентралізаційних змін. В першу чергу, місцеві органи самоврядування мають забезпечити підтримку процесів трансформації, дбаючи про задоволення потреб громади через попереднє виявлення цих потреб і прогнозування змін для окремо взятої місцевості.

\section{Список бібліографічного опису:}

1. Рейтинг BDO International Business Compass (IBC). URL: https://www.bdo.ua/uk-ua/insights-2/informationmaterials/bdo-internation-al-business-compass-2018

2. Бриль М., (2018). Стратегія - основа становлення та розвитку ОТГ. Місцеве самоврядування. No 5. URL: https://i.factor.ua/ukr/journals/ms/2018/may/issue 5/article 36538.html (дата звернення: 08.05.2021).

3. Івашина Л., (2017). Роль об'єднаних територіальних гро мад у розвитку сільського зеленого туризму. Державнеуправління та місцеве самоврядування. Вип. 3 (34).С.143-148.

4. Денисюк Г. Л. Форми і методи залучення та використання інвестицій для забезпечення інноваційного розвитку регіону. URL: https://eprints.oa.edu.ua/7049/ (дата звернення: 08.05.2021).

5. Пальчук В., (2018). Розвиток економічного потенціалугромад у рамках реформи з децентралізації. Україна:події, факти, коментарі.. No 11. С. $38-50$.

6. Сторонянської I.3., (2020). Територіальні громади в умовах децентралізації:ризики та механізми розвитку: монографія / за ред.Кравціва В.С., Львів: ДУ "Інститутрегіональних досліджень імені М.І. Долішнього НАНУкраїни. C. 531.

7. Кейс-стаді. Впровадження інвестиційних інструментів: на регіональному та муніципальному рівнях URL: https://decentralization.gov.ua/uploads/library/file/609/Case_Study_PLEDDG_Investments-web.pdf (дата звернення: 09.05.2021).

8. Гуренко А.М. Державна підтримка реалізації інвестиційних договорів за участю органів державної влади та органів місцевого самоврядування. URL: http://www.law.stateandregions.zp.ua/archive/1_2017/9.pdf (дата звернення: 09.05.2021).

9. Овчаренко Т. Моделювання ефективної фінансової діяльності органів місцевого самоврядування отг в умовах децентралізації.консолідований підхід. URL: https://decentralization.gov.ua/uploads/library/file/568/4.pdf (дата звернення: 10.05.2021).

10. Кабінет Міністрів України Постанова від 16 лютого 2011 р. N 110 Київ Про затвердження Порядку здійснення місцевих запозичень. - Режим доступу: https://zakon.rada.gov.ua/laws/show/110-2011-\%D0\%BF\#Text (дата звернення: 10.05.2021).

11. Москалюк Н. Б. Механізм корпоратизації як передумова до припинення права державної власності: історичні аспекти, сучасний стан і перспективи розвитку. URL: http://pyuv.onua.edu.ua/index.php/pyuv/article/view/514/816 (дата звернення: 12.05.2021).

12. Як залучити гранти для розвитку громад: поради старостам. URL: http://uccs.org.ua/novyny/iak-zaluchyty-hrantydlia-rozvytku-hromad-porady-starostam/ (дата звернення: 12.05.2021).

13. Державний фонд регіонального розвитку: гроші для розвитку чи проїдання? URL: https://cost.ua/730-derzhavnyyfond-rehionalnoho-rozvytku-hroshi-dlya-rozvytku-chy-proyidannya/ (дата звернення: 15.05.2021).

14. Міжмуніципальне співробітництво сприяе рівномірному розвитку OTГ. URL: https://decentralization.gov.ua/news/9018 (дата звернення: 15.05.2021).

15. Ковшова Олена. Ще не придбали ОВДП? Тоді ми йдемо до вас! Місцеве самоврядування Лютий, 2019/№ 2 URL: https://i.factor.ua/ukr/journals/ms/2019/february/issue-2/article-42480.html (дата звернення: 17.05.2021).

16. Яцек Адамчик, Мацей Копитек, Войцех Одзімек, Марія Пйонтковска. Посібник із залучення інвестицій URL: https://sambirrada.gov.ua/wp-content/uploads/2016/04/pos-zal-inv.pdf (дата звернення: 17.05.2021).

\section{References:}

1. Rating BDO International Business Compass (IBC). URL: https://www.bdo.ua/en-us/insights-2/information-materials/bdointernation-al-business-compass-2018oc used sources

2. Bril M., (2018). Strategy is the basis for the formation and development of OTG. Local Government. No 5. URL: https://i.factor.ua/ukr/journals/ms/2018/may/issue 5 / article 36538.html (access date: 08.05.2021)

3. Ivashina L., (2017). The role of united territorial communities in the development of rural green tourism. Public administration and local self-government. Vip. 3 (34) .C.143-148.

4. Denysyuk G.L. Forms and methods of attracting and using investments to ensure innovative development of the region. URL: https://eprints.oa.edu.ua/7049/ (access date: 08.05.2021)

5. Palchuk V., (2018). Development of economic potential communities in the framework of decentralization reform. Ukraine: events, facts, comments .. No 11. S. $38-50$. 
6. Storonyanska I.Z., (2020). Territorial communities in the conditions of decentralization: risks and mechanisms of development: monograph / edited by Kravtsiva V.S., Lviv: SI "Institute of Regional Studies named after MI Dolishny NANU of Ukraine. P. 531.

7. Case study. Implementation of investment instruments: at the regional and municipal levels URL: https://decentralization.gov.ua/uploads/library/file/609/Case_Study_PLEDDG_Investments-web.pdf (access date: 09.05.2021)

8. Gurenko A.M. State support for the implementation of investment agreements with the participation of public authorities and local governments. URL: http://www.law.stateandregions.zp.ua/archive/1_2017/9.pdf (access date: 09.05.2021)

9. Ovcharenko T. Modeling of effective financial activity of local governments in the conditions of decentralization. Consolidated approach. URL: https://decentralization.gov.ua/uploads/library/file/568/4.pdf (access date: 10.05.2021)

10. Cabinet of Ministers of Ukraine Resolution of February 16, $2011 \mathrm{~N} 110$ Kyiv On approval of the Procedure for local borrowing. - Access mode: https://zakon.rada.gov.ua/laws/show/110-2011-\%D0\%BF\#Text (access date: 10.05.2021)

11. Moskalyuk N.B. The mechanism of corporatization as a prerequisite for the termination of state ownership: historical aspects, current status and prospects for development. URL: http://pyuv.onua.edu.ua/index.php/pyuv/article/view/514/816 (access date: 12.05.2021)

12. How to attract grants for community development: tips for elders. URL: http://uccs.org.ua/novyny/iak-zaluchyty-hrantydlia-rozvytku-hromad-porady-starostam/ (access date: 12.05.2021)

13. State Fund for Regional Development: money for development or consumption? URL: https://cost.ua/730-derzhavnyyfond-rehionalnoho-rozvytku-hroshi-dlya-rozvytku-chy-proyidannya/ (access date: 15.05.2021)

14. Inter-municipal cooperation contributes to the balanced development of OTG. URL: https://decentralization.gov.ua/news/9018 (access date: 15.05.2021)

15. Kovshova Olena. Haven't bought IGLBs yet? Then we go to you! Local self-government February, 2019 / № 2 URL: https://i.factor.ua/eng/journals/ms/2019/february/issue-2/article-42480.html (access date: 17.05 .2021 )

16. Jacek Adamczyk, Maciej Kopytek, Wojciech Odzimek, Maria Piontkowska. Investment Attraction Guide URL: https://sambirrada.gov.ua/wp-content/uploads/2016/04/pos-zal-inv.pdf (access date: 17.05.2021)

Дата подання публікації 20.05.2021p.

\title{
УДК 373.61
}

Рудь Н.Т., д.е.н., професор

Rud N. Doctor of Economic Sciences, Professor https://orcid.org/0000-0002-9040-146X Богатко Б.В., студент гр. ЕК-41

\section{СТАРТАПИ: ТЕНДЕНЦІЇ РОЗВИТКУ ТА РИЗИКИ}

\author{
Луиький національний технічний університет
}

У статті вказано на актуальність розвитку стартапів, що набувають великого поширення у всьому світі. Основною проблемою для розвитку стартап-компаній в Україні є відсутність підтримки 3 боку держави і недостатність фінансування. Компанії зацікавлені вкладати свої кошти лише у кращі проєкти, які матимуть прибуток. Саме об'єднання зусиль учасників у процесі розробки й комерціалізації інновацій приведе до ефективного нарощування потенціалу іх розвитку у реалізованих ними інноваційних проєктах.

Досліджено поняття стартап та сформульоване авторське: стартап $-\epsilon$ новою інноваиійною структурою, яка реалізує бізнес-ідею в умовах невизначеності, що потребує грамотного управління ризиками.

Виділено особливості й переваги стартапу: ключова роль проєкту, глобалізаційна діяльність і глобальний розвиток стартапів в світі. Для знаходження інвесторів проєкту рекомендовано скласти стратегічний план пошуків, проаналізувати кілька подібних проєктів та зробити оцінку. Необхідно використовувати соціальні мережі, створити власний веб-сайт. Систематизовано ризики формування стартапів, наведено заходи щодо можливості їх усунення. Проаналізовано типові стадії, які проходить стартап в процесі свого розвитку і виділено специфічні ризики на кожній стадії.

Виділено основні ризики розвитку інноваційних проєктів. Показано ефективність використання інноваційних проєктів. Розглянуто основні види інноваційних проєктів та наведено їх характеристики. Проаналізовано види, приклади успішних українських інноваційних проєктів. Відмічено переваги та 
недоліки стартапу: інформативність, висока результативність, велике охоплення цільової аудиторії, забезпечення потреб споживачів, нераціональне використання коштів та інше.

Ключові слова: стартап, інноваційний проєкт, фінансування, стадї, ризик. 